\title{
DIPLOMACY AS DEPICTED IN THE MATSYAPURĀNA
}

\section{Dr. Binima Buzarbaruah}

\begin{abstract}
A bstract
Purānas occupy a very significant position in the vast treasury of Sanskrit literature. Purānas deal with various branches of knowledge. The Matsyapurāna, like some other Purānas, supplies the materials relating to the statecraft apart from other different topics. Diplomacy is an integral Part of the governance of a state and various aspects relating to diplomacy are well delineated in the Matsyapurāna. A variety of measures regarding diplomacy, found in this Purāna, possesses high moral standard. With the analysis of the policies, it can be well noticed that this Puraña has made a great endeavour to establish peace in a state with an expectancy of least amount of bloodshed. This is a principle which is significant for all times to come.
\end{abstract}

Diplomacy plays a significant role in the international relation of a state. The term diplomacy is defined as the process of representation and negotiation by which states customarily deal with one another in terms of peace. It is an application of tact and intelligence and the conduct of official relations between the governments of independent states. ${ }^{1}$ Different ancient Sanskrit treatises have dealt with diplomacy very vividly, of which the Purāna literature is worth mentioning. Purānas are considered to be a very important branch in Sanskrit literature which besides fulfilling their special characteristics, are the storehouse of the varied field of society and culture of ancient India. Amongst the eighteen Mahāpurānas, the $M$ atsyapurāna has a very high position. Various rules regarding the statecraft are found to be well delineated in this Purāna. Interstate relation which plays a major role in the administration of a state has occupied a significant place in the Matsyapurāna. 
For a successful and perfect inter relations, that which is considered to be the very basis, is the application of proper policies. Different treaties of Sanskrit literature have generally recognised six fold methods of diplomacy. Those six fold policies are sandhi or alliance, vigraha or war, yāna or marching, āsana or camping, dvaidhibhava or dichotomy and samiśraya or seeking refuge. Alliance is the making agreement with pledges. Offensive operation is war. Marching is sometimes used alone when an urgent matter arises and sometimes accompanied by an ally. Camping is applied when the king is weakened by fate or by his former deeds or to oblige an enemy. Dichotomy is the placing of the army and the king in two different places. Seeking refuge is said to be of two kinds- when a king is oppressed by the enemies and takes refuge to save his wealth and when he is among virtuous kings and takes refuge to prevent danger. ${ }^{2}$ However, there is no elaborate discussion in the Matsyapuranna regarding these sixfold policies. This Purāna has laid stress on the seven means which were to be undertaken by a king. These means are viz. sama i.e the policy of conciliation, dana i.e. the gift, bheda i.e the divide and rule, daṇ̣a i.e. punishment, upekșā i.e. neutrality, māyā i.e. illusion and indrajāla i.e.magic. ${ }^{3}$

The Matsyapurāna in very clear terms describes about the application of sama or the policy of conciliation. It has shown two fold divisions of sāma viz. tathyasama i.e. the policy of genuine conciliation and atathyasama i.e. perfidious policy of conciliation. The tathyasāma or the policy of genuine conciliation was restricted in its application to certain kinds of persons. it is directed to be applied only to the righteous kings. The Matsyapurāna also rightly instructs the king as to how this policy is to be utilised. It is very necessary for a king to appreciate the kings through tathyasāma. The kings should be admired by praising their lineages, and also by telling their good deeds. Their high pedigree and the deeds done for other's benefit are to be described. This is the way by which the righteous persons can be brought under control. The Matsyapurāna prohibits a king from applying the atathyasama to a righteous person as it produces bitter feelings in them. This purāna repeatedly states that the policy of conciliation wins all. But it should never be applied in the case of wicked and unrighteous persons. ${ }^{4}$ Thus, the king should be made himself mindful in 
deciding on whom this should be applied. It is the conduct and the nature of the person which should be considered first before the application of this policy.

The second important policy for diplomacy is dāna or gift. it is considered as the most excellent amongst all the prescribed means according to the Matsyapurāna. Dāna or gift has so much power that a man is stated to be able to win both the worlds by giving gifts in virtuous manner. It is stated that by this even gods may be influenced and conquered by the mortals. A person inferring gifts is stated to be loved by all. A donor sovereign can easily conquer his single enemies and also those conjoint together, by gifts and presents. The influence of gift is such that it can bring even the grave people who do not have covetousness, to the side of the sovereign. ${ }^{5}$

The third policy i.e. the divide and rule should be applied to those who are hostile and wicked to one another and consider themselves insulted. The faults for which certain people became disagreeable to others, they should be imputed to the latter. It is for the purpose of bringing disunion amongst them. They should be made aware about their own faults and should befrightened by the opposite party. In this way, certain class of people can be brought under submission dividing them from their party. Matsyapurāna declares that it is only with the help of disunion that a king can be able to become successful, as it is not possible for Indra also to conquer the united ones without creating disunion. ${ }^{6}$

The Matsyapurāna also instructs that a sovereign should not launch personally the policy of bheda. To make it more effective this purāna suggests that it should be done through another agency. This purāna alerts the king from the possibility of disunion amongst his own community while taking the divide and rule policy and suggests to prevent it very cautiously. It states that when the kith and kin are distressed then they often produce suffering. Therefore, they should be kept united by gifts and royal regards. A dissension among them is stated to be very dangerous to a sovereign. With the application of bheda policy the Matsyapuranana rightly declares that even the strongest enemies can be conquered by a small force ${ }^{7}$ 
The fourth expedient is the policy of danda which has been shown as of least importance in comparison with other policies. There are twofold divisions of danda. One is applied in one's own country and the other is applied in the foreign countries. ${ }^{8}$ The punishment which is to be applied in the foereign states is again has two divisions viz. prakāśa i.e. open and aprakāśa i.esecret. ${ }^{9}$ The prakāśa punishment consisted of loot, ruining village, destroying crops, setting fire and so on. However, secret murder, polluting water etc. come under the aprakāśa daṇ̣̂a. A sovereign should punish those who deviate from their prescribed order or duties. It is found in the Matsyapurāna that an intelligent king should apply the policy of danda according to prescribed rules. While using this policy the king should have consultation with different persons like the vānāprasthins, knower of dharma, those who are devoid of love etc. Moreover, while inflicting punishment the king must see whether the justice has been properly maintained or not. If a king inflicts punishment on the innocent and at the same time lets off the guilty ones, then according to the Matsyapurāna, such a king not only loses his realm in this world but also goes to hell in the next. ${ }^{10}$

While using punishment the king should have the aim in his mind, for the welfare of the beings. When a king inflicts punishment properly after due consideration he is adored by god. Those who are contrary to it are always dishonoured. Laying stress on the use of punishment without discrimination the Matsyapurāña opines that such a sovereign is respected even more than gods like Brahmā, Agni, Indra, Sürya and so on. The Matsyapurāna mentions two fold object of punishment viz. to punish the wicked people doing some wrongful activities and to prevent others from committing some fresh sins. So, the very purpose of applying this means should bethe welfare of the beings. It is the suggestion of the Matsyapuranna that in the general circumstances, a king should not apply this policy. However, it instructs the king to adopt this policy only when other three policies do not yield good result. ${ }^{11}$ So it should be taken up as the last resort.

A part from these four, other three expedients have also been mentioned in the Matsyapurāna. Those are upekșa i.e. indifference, 
māyāi.e. illusion and indrajāla i.e.magic. The policy of indifference or upeksa is taken up when the other policies cannot be possible to be applied. Māyā is used in the sense of illusion. The illusory power is used to mislead the enemies and it also hits them in their weak points. The seventh and the last policy is stated to be indrajala or magic, which also a king may apply for winning over his enemies. The Agnipurāna explains that this consisted of frightening the enemies by artificial clouds, darkness, rains and hills or making a view of a large army marching down upon them, in the manner of meeting them in the battle field. The purpose of applying this is to make the soldiers of enemy depressed and also to strike them with fear. ${ }^{12}$

The diplomatic agents play a great role in the maintenance of the relationship with other states. These employees of the state gather information about the foreign states. There are two diplomatic agents viz. ambassador and spies. The ambassadors were assigned only with the duties of the external affairs of the state, while, the spies were entrusted with the responsibility of the internal affairs of the state also. Regarding appointment of those it is stated that the ambassadors were appointed openly and on the other hand the spies were appointed secretly. ${ }^{13}$ There are three different divisions of ambassadors viz. nișrstärtha, mitārtha and śāsanahāraka, each one of which has been entrusted with different kinds of powers and responsibilities. The nișrstārtha, or plenipotentiaries were given preliminary powers to discuss and conclude terms with foreign powers and also to issue ultimatums. The mitārtha had some restricted powers and had some rights of initiative. The saasanahāraka, only obeyed their masters and had to repeat every word of a message without changing anything. ${ }^{14}$ Certain essential qualifications of an ambassador also are mentioned in the Matsyapurāna. Here, it is stated that the ambassador should be very much conscientious for submitting true reports. He should be obedient to the king and should know languages of many countries. He should be eloquent and able to spend a troublesome life etc. ${ }^{15}$

In diplomacy, role of spy is very important. Matsyapurāna laid stress on the need of spies. According to Matsyapurāna, a king should depute four spies in his country and in foreign countries for 
the purpose of the policy of divide and rule. Certain qualifications of the spy also have been fixed in this Purāna. The spies should be intelligent, well versed in scriptures, of good conduct, should not be identified by others, of simple habit and skilful in trade and medicine. The spies should have the capacity to identify each other and should be of gentle manner. Matsyapurāna also mentions how the spies should roam. According to this puranna spies should take the form of merchants, ministers, astrologers, physician or sannyāsas. It is stated that everything in a state is depended upon spies. However, a king should not trust one spy alone and also he should have a careful look on them. The spies should be checked in return. ${ }^{16}$

Thus, the diplomatic measures needed for the interstate relations are delineated in the Matsyapurāna in a very exhaustive and vivid manner. These are having great worth and high moral standard. With the analysis of the policies mentioned in the Matsyapurāna, it is observed that the Matsyapurāna in very clear terms instructs the kings regarding the time when the policies are to be undertaken and the way how these are to be applied. The King, for the greater interest of the state is instructed to avoid war and make efforts for peace with other states. The fourth policy i.e. danda is given the least importance, whereas the danna is shown as having the highest value which a king should take resort to. So, during that time, smallest amount of bloodshed was expected. Moreover, the officials who were associated with the interstate relations are directed to take shelter of the righteousness while dealing with other states. Thus, a remarkable effort to have peaceful atmosphere amongst the states which is ever welcomed, has been made by the Matsyapurāna in the true sense of the term.

\section{References:}

1. Chandra Prakash, Theories of International Relations, Vikash Publishing House Pvt. Ltd., New Delhi, 2008, p.113.

2. Manusmeti, 7.159-168

3. Sāma bhedastathā dānami danḍ̂́ca manujesvara. Upekșā ca tathā māya indrajāla ca pārthiva.. M atsyapurāṇa, 222.2

4. Ibid, 222.4-7

5. Ibid, 224.1-5

6. Ibid, 223. 1-4 
7. Ibid, 223.6,13,14,16

8. Jaiswal, S.K., Polity and Administration in the Matsyapurāna, Publication Scheme, Jaipur, 1996, p.178

9. Agnipurānăa, 234.1

10. Matsyapurāna, 225.2-6

11. Ibid, 225.1-17

12. Agnipurāna, 234.5-15

13. Supra, Note 8, p.180

14. Ibid., p.181

15. yathoktavādī dūtah syāddeśabhāṣâvi śāradah. śaktaḥ kleśasaho vāgmī deśakālavibhāgavit. vijñătadeśakâlaśca dūtah sa syānmahikșitah. vaktā nayasya yaḥ kälesa düto nụpaterbhavet.

Matsyapūrāna, p. 215.12-13

16. Ibid, p.215, 90-95

\section{Bibliography :}

1. Arthaśāstra of Kautilya, Ganapatisastri, T, New Bharatiya Book Corporation, Delhi, 2006

2. Matsya Mahāpūrāṇa, Joshi, K.L., Parimal Publications, Delhi, 2007

3. Agnipūrānam, Panchanan Tarkaratna Navabharat Publishers, Kolkata, 1999

4. Chandra Prakash, Theories of International Relations, Vikash Publishing House Pvt. Ltd., N ew Delhi, 2008

5. Heywood, Andrew, Key Concepts in Politics and International Relations, palgrave, London, 2015

6. Doniger, Wendy, The Laws of Manu, Penguine Classics, London,2000

7. Pandey, Chandra, Anup, Governance in Ancient India, D.K. Printworld Pvt. Ltd., New Delhi, 2000

8. Aiyar, K.Narayanaswami, The Pürānas, Cosmo Publications New Delhi,2003 